\title{
Osteological alterations in the tucuxi Sotalia fluviatilis (Cetacea, Delphinidae)
}

\author{
Daniela de C. Fettuccia ${ }^{1}$, Vera M. F. da Silva ${ }^{1} \&$ Paulo C. Simões-Lopes ${ }^{2}$ \\ 1. Laboratório de Mamíferos Aquáticos, Instituto Nacional de Pesquisas da Amazônia, 69060-001, Manaus, Amazonas, Brazil (fettuccia@hotmail.com; tucuxi@inpa.gov.br) \\ 2. Laboratório de Mamíferos Aquáticos, Departamento de Ecologia e Zoologia, Universidade Federal de Santa Catarina, 88040-970, Florianópolis, Santa Catarina, Brazil (lamaqsl@ccb.ufsc.br)
}

\begin{abstract}
We present a description of osteological alterations observed in the tucuxi, Sotalia fluviatilis (Gervais, 1853) from a sample of 43 specimens. Fractures were the most frequent alterations in the sample (16\%), occurring in various regions of the skeleton such as the ribs, hyoid apparatus, transverse and neural processes of vertebrae and scapula. We observed three individuals with ankylosis between the cervical vertebrae and two individuals with morphological changes (cranio-caudally elongated hemal arch and flattened cranial margin of the scapula). The only observed pathology was a case of osteomyelitis in the left dentary, which caused the loss of teeth, deformation of the associated alveoli and the formation of a medial fistula (lingual) for drainage of purulent material. This represents the first record of osteomyelitis in S. fluviatilis.
\end{abstract}

KEYWORDS. Pathology, bone fractures, ankylosis, osteomyelitis.

RESUMO. Alterações osteológicas no tucuxi Sotalia fluviatilis (Cetacea, Delphinidae). Apresenta-se a descrição das alterações ósseas observadas no tucuxi, Sotalia fluviatilis (Gervais, 1853) de uma amostra de 43 exemplares. As fraturas foram as alterações mais frequentes na amostra (16\%), ocorrendo em diversas regiões do esqueleto como costelas, aparato hioide, processos transversos e neurais das vértebras e escápula. Foram observados três indivíduos com anquilose entre vértebras cervicais e dois com alterações morfológicas (arco hemal alongado no sentido crânio-caudal e escápula com borda cranial plana). A única patologia registrada foi um caso de osteomielite no dentário esquerdo, o que ocasionou a perda de dentes, a deformação dos alvéolos no local e a formação de uma fístula medial (lingual) para drenagem de material purulento. Este é o primeiro registro de osteomielite para a espécie.

PALAVRAS-CHAVE. Patotogia, fratura, anquilose, osteomielite.

The study of pathologies and other alterations in the bones and teeth of extant and fossil mammals has permitted an indirect mean to understanding adaptive processes, habits, lifestyle and diet, biomechanical and nutritional diseases. The correct identification of anatomical variation from specific patterns is fundamental in Zoology, where the frequent lack of such knowledge often leads to taxonomic errors (Ferigolo, 1987). Different events can leave permanent marks on the bones and reveal important aspects of the life history of a particular animal, but it is not always a simple matter to recognize which processes are involved (SimÕEs-LOPES et al., 2008).

Bone fractures, pathological processes, malformations, deformities or alterations related to senescence in cetaceans have been noted in the literature by various authors (PuRves \& VAN BREE, 1972; DE SMET, 1977; Odgen et al., 1981; Kompanje, 1995a; Berghan \& Visser, 2000; Montes et al., 2004; FÉLIX et al., 2007; VAN BRESSEM et al., 2007; OREMLAND et al., 2010, Hellier et al., 2011; GROCH et al., 2012; MARIGO et al., 2013), however, there is persistent confusion regarding certain terminology, the causes and biomechanical consequences of such incidents, sometimes leading to the use of the same term for different osteological features (SimõEs-Lopes et al., 2008).

Fractures in different regions of the skeleton, deformities, adaptive changes in response to aging of the spine and diseases of exogenous origin have been previously recorded for Guiana Dolphins Sotalia guianensis (Van Bénéden, 1864) (FurTado \& SimõesLOPES, 1999; vAN BRESSEM et al., 2007; SIMÕes-LOPES et al., 2008), but until now this subject has not been addressed in its congener, the tucuxi [Sotalia fluviatilis (Gervais, 1853)]. The current study aims to detail some of the osteological alterations that have been observed for the first time in S. fluviatilis individuals from different areas of the Amazon basin.

\section{MATERIAL AND METHODS}

We examined 43 partial and complete skeletons of Sotalia fluviatilis from various localities throughout the Amazon basin and deposited in the following scientific collections: Instituto Alexander von Humboldt, Colombia (IAVHM 7345), Instituto Nacional de Pesquisas da Amazônia, Brazil (INPA MA 003, 005, 007-009, 015-018, 020, 024, 026, 029, 038-041, 043, 047, 050-057, 059, 060, 062, 065, 067, 069, 073, 074, 081, 093, 097, 113, INPA MA NC 1013) and the Museu de Zoologia, Universidade de São Paulo, Brazil (MZUSP 18948, 18949).

Observed changes from regular osteological pattern in these skeletal specimens were grouped into three distinct categories: disease (osteomyelitis), trauma and atypical morphological changes according KOMPANJE (1999). We analyzed specimens representing all age groups, determined according to the degree of fusion in cranial sutures and vertebral epiphysis (DAWBIN et al., 1970; Perrin, 1975; Ito \& MiYazaKi, 1990). Diagnoses and descriptions were realized according to the methods of Kompanje (1995a,b, 1999), van BRESSEM et al. (2007) and Simões-Lopes et al. (2008). 


\section{RESULTS}

We observed 11 cases of osteological alterations in $25.6 \%$ of all the samples (Tab. I). No osteological alterations associated with senescence were observed.

Changes due to pathology. Osteomyelitis: We found one case of osteomyelitis (infectious spondylitis) in the midline region of the left dentary bone of one specimen (INPA MA 056). Inflammation caused the loss of teeth, local deformation of the alveoli and the formation of a medial fistula (lingual) for the purpose of draining purulent material (Fig. 1, Tab. I).

Changes due to trauma. Fractures were the most frequently osteological alterations observed, representing about $16 \%$ of all samples and occurring in different regions of the skeleton (Figs 2-5, Tab. I). Fractures of the neural processes of caudal vertebrae Ca4-7 (INPA MA 113), in the transverse processes of thoracic vertebrae To9-To11 (INPA MA 20), in the scapula (subscapular fossa) (INPA MA NC 1013), sternal ribs (INPA MA 18) and the hyoid (thyrohyal) (INPA MA 016; 20) were consolidated and marked by ossified calluses. Rib fractures in two specimens (INPA
MA 39; 40) occurred in medial position and were not fully consolidated.

Ankylosis. Three cases of ankylosis of the cervical region (Ce) in an adult specimen of Sotalia fluviatilis were observed. One specimen (INPA MA17) presented ventrally fused vertebrae (Ce3-4), while two other individuals (INPA MA 57 and 73) showed fusion of the transverse ventral lamina of $\mathrm{Ce} 6$ and Ce7. In all three cases, the vertebrae did not show any other osteological changes apart from the unusual bone fusion.

Morphological alterations. Two types of morphological alterations, or the occurrence of unusual formations, were observed. One specimen (INPA MA 018) presented a chevron bone (hemal arch) with elongated processes and a nonconsolidated fracture. Another specimen (INPA MA 055) presented flattened cranial edges of the scapula, different from the commonly observed morphology of S. fluviatilis (Figs 6-8). There were no clear cases of malformation in the sample. However, vertebrae with open neural canals $(\mathrm{Ce} 3)$ were observed in about $90 \%$ of the specimens $(n=25)$. In Ce4 the frequency of open neural canals was lower, occurring in just $20 \%$ of all the specimens examined.

Tab I. Sotalia fluviatilis (Gervais, 1853) (tucuxi) samples showing osteological alterations ( $\mathrm{n}=11$, from a total of 43 specimens examined) (Ad, adult; Sub, subadult; Cal, calf; I, indeterminate sex; M, male; F, female; Ce, cervical vertebra; Ca, caudal vertebrae)

\begin{tabular}{lcccl}
\hline Specimen & Sex & Age & Location & Observed change(s) \\
\hline INPA MA 016 & I & Ad & Japurá River & consolidated fracture of the hyoid \\
INPA MA 017 & M & Ad & Japurá River & ankylosis Ce3-4 (ventral region of the vertebral body) \\
INPAAM 018 & I & Cal & Japura River & consolidated fracture of the first sternal rib; hemal arch anomaly \\
INPA MA 020 & I & Ad & Japurá River & healed fractures in the transverse process of To9-11 and hyoid \\
INPA MA 039 & M & Sub & Japurá River & unconsolidated fracture in the sixth vertebral rib (left) \\
INPA MA040 & F & Ad & Amanã Lake & healed fractures in the seventh and eighth vertebral ribs (left) \\
INPA MA056 & F & Ad & Amazon River & osteomyelitis in the left dentary \\
INPA MA057 & F & Ad & Amazon River & ankylosis Ce6 -7 (lateral lamina of Ce6) \\
INPA MA073 & F & Ad & Purus River & ankylosis Ce6 -7 (lateral lamina of Ce6) \\
INPA MA 113 & M & Ad & Solimões River & consolidated fracture of the neural process (Ca4-7) \\
INPA MA NC 1013 & M & Ad & Japura River & consolidated fracture of the scapula \\
\hline
\end{tabular}

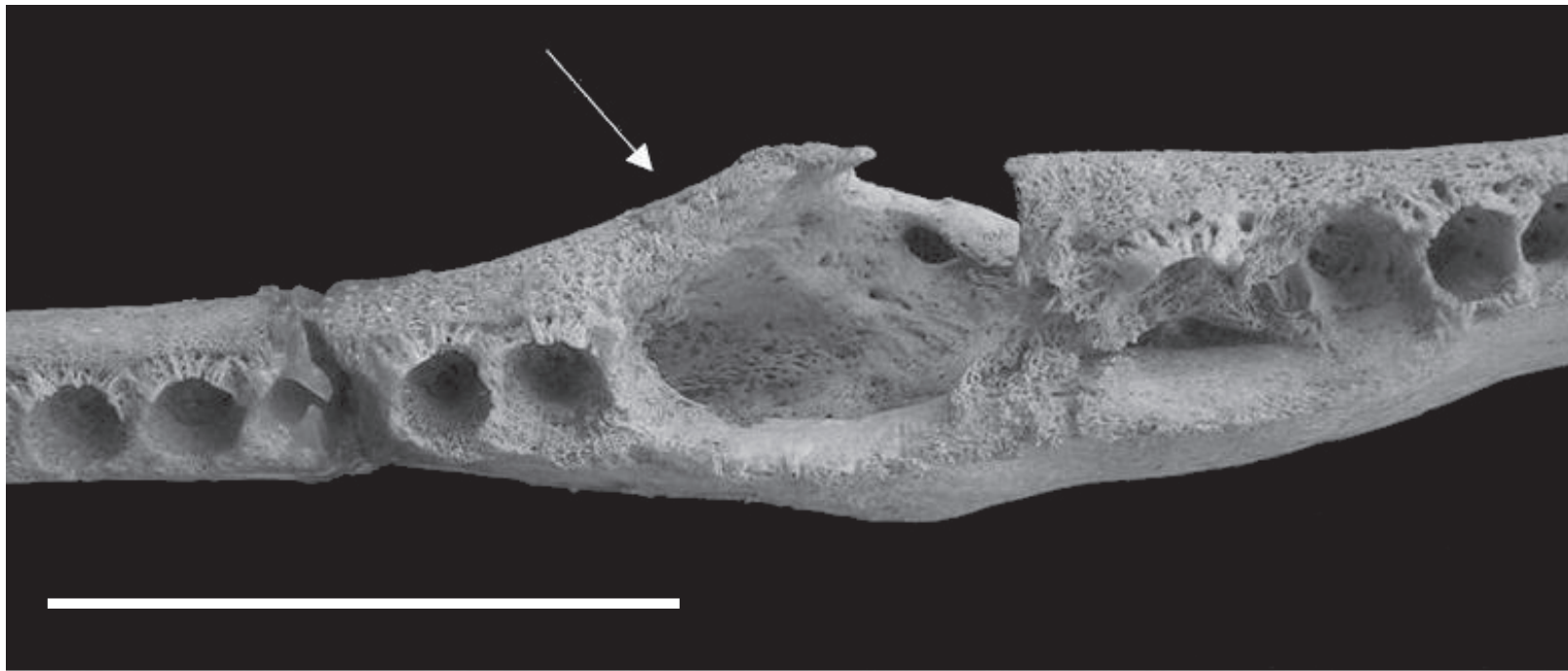

Fig 1. Occlusal view of the left dentary of Sotalia fluviatilis (Gervais, 1853) (INPA MA 056) modified by osteomyelitis. The medial region of the dentary shows the formation of a fistula and deformation of the alveoli. Pathology indicated by the arrow. Scale bar, $3 \mathrm{~cm}$. 

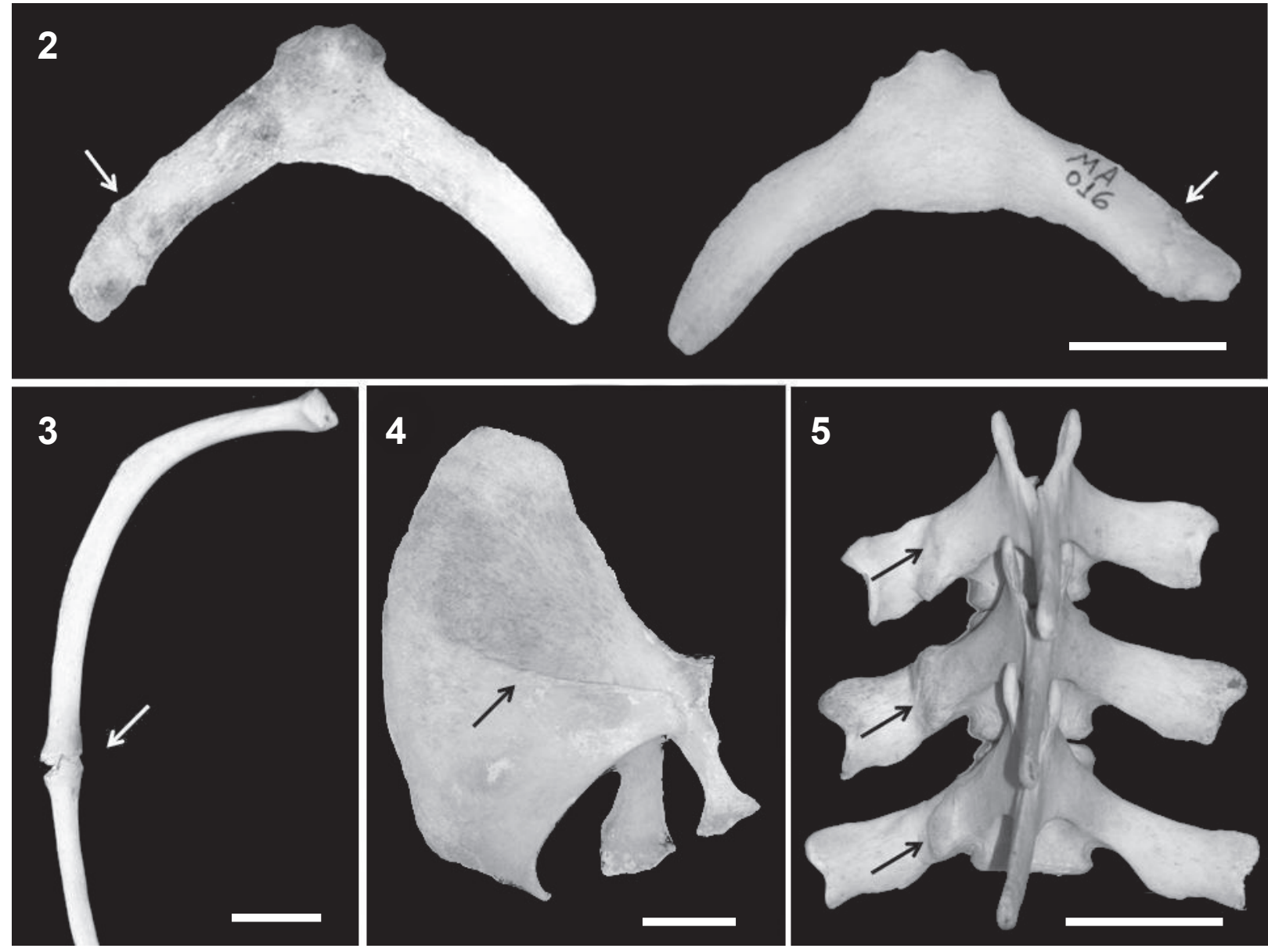

Figs 2-5. Different bone fractures observed in Sotalia fluviatilis (Gervais, 1853) (arrows): 2, thyrohyal (hyoid) (MA020 and INPA 016); 3 , rib (INPA MA 039); 4, scapula (INPA MA NC 1013); 5, thoracic vertebrae (To9-11), with a fracture in the right transverse process (INPA MA 020). Scale bars, $3 \mathrm{~cm}$.
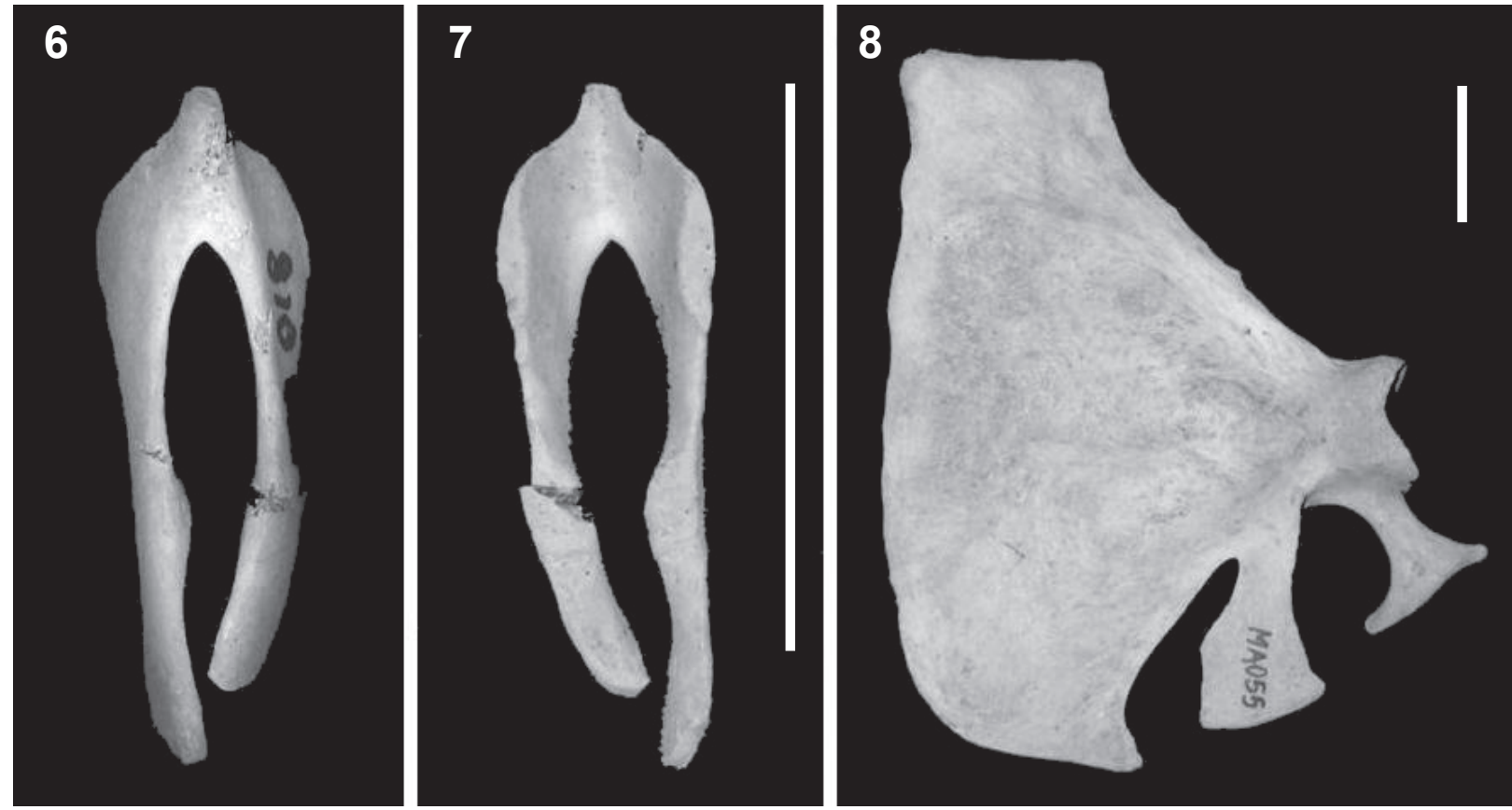

Figs 6-8. Unusual morphologies observed in Sotalia fluviatilis (Gervais, 1853): 6 and 7, atypical formation of the hemal arch (INPA MA 018) shown in the dorsal and ventral views; 8 , scapula with flattened cranial edge (INPA MA 055). Scale bars, $3 \mathrm{~cm}$. 


\section{DISCUSSION}

Osteomyelitis is a condition whereby some bacterial agent causes the inflammation of connective tissues and bone marrow (Jones et al., 2000). The occurrence of osteomyelitis in dental alveoli changes is the most common infectious nature in the skeletons of dolphins and occurs secondary to dental infections (SWEENEY, 1978). There are reports of osteomyelitis occurring in the oral region and the spine of Sotalia guianensis (vAN BRESSEM et al., 2007; SimÕES-LoPes et al., 2008), Orcinus orca (Linnaeus, 1758) (Kompanje, 1995c), Lagenorhynchus albirostris (Gray, 1846) (Kompanje, 1995b), Phocoena spinipinis Burmeister, 1865 (Montes et al., 2004), Globicephala melas (Traill, 1809) (SweEney et al., 2005), Pontoporia blainvillei (Gervais \& d'Orbigny, 1844) (GERHOLDT, 2006), Delphinus capensis Gray, 1828 (Loch et al., 2011; vaN BRESSEM et al., 2007), Tursiops truncatus (Montagu, 1821) and Pseudorca crassidens (Owen, 1846) (vAN BRESSEM et al., 2007); Megaptera novaengliae (Borowski, 1781) (Felix et al., 2007). KomPANGE (1995c) suggested that dental injuries can function as a "gate" for infectious agents, since these infections are usually followed by penetrating wounds or fractures (JoNES et al., 2000), or simply by normal wear and tear of the teeth that may eventually expose the pulp cavity, creating a mean of entry for infectious agents (DREHMER et al., 1998). The current study represents the first report of osteomyelitis occurring in Sotalia fluviatilis.

Fractures have also been reported in cetaceans (SWeENEY \& Hidway, 1975; Simões-Lopes et al., 2008; GROCH et al., 2012). The locations and types of fractures that have been observed in cetaceans can be related to distinct causes, such as surface fractures of the fins, scapula, ribs or jaw being caused by agonistic interactions or even collisions with boats (DE SMET, 1977; OGDEN, 1981; Montes et al., 2004; Gerholdt, 2006; SimõesLOPES et al., 2008). However, deeper fractures, such as those which may occur in the transverse and neural processes of the vertebrae, cannot be easily attributed to external trauma, since these bones are protected by an extremely thick layer of fat and muscle (DE SMET, 1977; SimÕEs-LOPES et al., 2008). These types of fractures may be caused by excessive tension on the osteo-articular tendon structures. In such cases, it is possible that stress fractures related to locomotors muscles of cetaceans have origins in these processes especially in the thoracic region and lumbar region that serves as a potent source for the locomotor muscles of cetaceans (SIMÕES-LOPES et al., 2008). Fractures of the hyoid apparatus must present a distinct and still unknown origin.

On the other hand, ankylosis of vertebrae is usually associated with fractures and osteomyelitis or spondyloarthritis, reducing the range of movement of the affected structures (KOMPANJE, 1995a,b, 1999; Montes et al., 2004). However, the formation of large bulky syndesmophytes replacing the other parts of annulus fibrosus and leaving to an intervertebral bridge are typical from the spondyloarthritis (KoMPANJE, 1999).

Anatomical variation is not always a synonymous of pathology (FERIGOLO, 1987), however, it is difficult to determine whether such variation reflects cases of congenital malformation or if it is simply a part of normal intra-specific morphological variation. The presence of an open neural canal in the cervical vertebrae (particularly in the $\mathrm{Ce} 3$ and $\mathrm{Ce} 4$ ) has been previously documented as a typical characteristic of S. guianensis in southern Brazil (FetTUCCIA \& SimõEs-Lopes, 2004). However, observations of the cervical vertebrae in specimens of $S$. guianensis from other locations in South America confirm that an open neural process may also occur in the $\mathrm{Ce} 7$ in 19 to $30 \%$ of all individuals of this species $(\mathrm{n}=222)$ (unpublished data) and as much as $20 \%$ of $S$. fluviatilis individuals $(\mathrm{n}=31)$. Thus, the open neural canal in $\mathrm{Ce} 3, \mathrm{Ce} 4$, and $\mathrm{Ce} 7$ observed here is interpreted as a commonly observed feature in the two species of Sotalia, rather than a congenital malformation as suggested by VAN BRESSEM et al. (2007) and LAETA et al. (2010).

This particular case reinforces the importance of studies addressing intraspecific and interspecific morphological variation, to avoid erroneous generalizations about certain taxa, such as attributing what is actually normal variation to a case of pathology or malformation. For example, degenerative joint diseases of the human spine have long been erroneously attributed to the stress of maintaining an upright posture. However, studies of the quadruped mammals, which do not assume an upright posture, have shown that the onset of such changes in aquatic animals is actually quite common and not exclusive to bipedal animals (Ferigolo, 1983).

Pathological skeletal changes were found to be uncommon in S. fluviatilis, but this may be related to the limited sample size of the sample in regards to individuals with complete skeletons. We stress the importance of analyzing complete skeletons in studies that aim to make inferences about entire populations, considering the real possibility of underestimating the degree of osteological alterations, since very often only the skull is collected and pathologies can be limited to other parts of the skeleton.

Acknowledgements. We are grateful to Rodrigo S. Amaral and Daniel Pimpão for their suggestions on the manuscript. We are thankful to $\mathrm{CNPq}$ for financial support and to the curators of the institutions that allowed us access to their osteological collections: specifically, Javier Maldonado (Instituto Humboldt, Villa de Leiva, Colombia); Maria Nazareth F. da Silva (INPA, Manaus, AM, Brazil); and Mario de Vivo (MZUSP, São Paulo, Brazil).

\section{REFERENCES}

BERGHAN, J. \& VISSER, I. N. 2000. Vertebral column malformation in New Zealand delphinids with a review of cases world-wide. Aquatic Mammals 26:17-25. 
Dawbin, W. H. N.; Nobel, B. A. \& Fraser, F. C. 1970. Observations on the electra dolphin, Peponocephala electra. Bulletin of the British Museum (Natural History) 20(6):173-201.

DE SMET, W. M. A. 1977. The regions of the cetacean vertebral column. In: HARrison, R. J. ed. Functional Anatomy of Marine Mammals. London, Academic Press. p.59-80.

Drehmer, C. J.; Ferigolo, J. \& Borsato, E. S. 1998. Ocorrência de Mirounga leonina Linnaeus (Pinnipedia, Phocidae) no ExtremoSul do Brasil: Agressão e Patologias. Revista Brasileira de Zoologia 15(4):1061-1068

Félix, F.; HaAse, B. \& Aguirre, W. E. 2007. Spondylitis in a humpback whale (Megaptera novaeangliae) from the southeast Pacific. Diseases Aquatic Organisms 75:259-264.

Ferigolo, J. 1983. Paleontologia em preguiças terrícolas - artroses. In VIII Congresso Brasileiro de Paleontologia. Resumos... Brasília, Sociedade Brasileira de Paleopntologia. p. 35-41.

1987. Anatomia comparada, paleontologia e paleopatologia de vertebrados. Paula-Coutiana 1:105-127.

Fettuccia, D. C. \& Simões-Lopes, P. C. 2004. Morfologia da coluna vertebral do boto-cinza, Sotalia guianensis (Cetacea, Delphinidae). Biotemas 17(2):125-142.

Furtado, M. H. \& Simões-Lopes, P. C. 1999. Alterações senildegenerativas e variações anatômicas na coluna vertebral de pequenos cetáceos. Biotemas 12(1):133-147.

Gerholdt, J. M. 2006. Abnormalities and Pathologies in the Snout of the La Plata Dolphin (Pontoporia blainvillei). The Ecphora 21:1-5.

Groch, K. R.; Marcondes, M. C. C.; Colosio, A. C. \& Catão-Dias, J. L. 2012. Skeletal abnormalities in humpback whales Megaptera novaeangliae stranded in the Brazilian breeding ground. Diseases Aquatic Organisms 101:145-158.

Hellier, C. A.; Hufthammer, A. K. \& Lislevand, T. 2011. Osteological pathology in a Humpback (Megaptera novaeangliae) and Fin (Balaenoptera physalus) whale skeleton. International Journal of Paleopathology 1:117-120

Ito, H. \& MiYaZAKI, N. 1990. Skeletal Development of the Striped Dolphin (Stenella coeruleoalba) in Japanese waters. Journal of the Mammalogical Society of Japan 14(2):79-96.

Jones, T. C.; Hunt, R. D. \& King, N. W. 2000. Patologia Veterinária. 6ed. São Paulo, Manole. 1415p.

Kompanje, E. J. O. 1995a. Differences between spondylo-osteomyelitis and spondylosis deformans in small odontocetes based on museum material. Aquatic Mammals 21:199-203.

1995b. On the occurrence of spondylosis deformans in white-beaked dolphins Lagenorhynchus albirostris (Gray, 1846) stranded on the Dutch coast. Zoologische Mededelingen Leiden 69:231-250.

1995c. Strandings of killer whale Orcinus orca in the Netherlands between 1783 and 1995 with some remarks on skeletal and dental pathology (Mammalia, Cetacea, Odontoceti). Deinsea 2:67-82

1999. Considerations on the comparative pathology of the vertebrae in Mysticeti and Odontoceti; evidence for the occurrence of discarthrosis, zygarthrosis, infectious spondylitis and spondyloarthritis. Zoologische Mededelingen Leiden 73:99-130.
Laeta, M.; Souza, S. M. F. M. \& Siciliano, S. 2010. Anomalias ósseas congênitas em Sotalia guianensis (Mammalia, Cetacea, Delphinidae) da costa centro-norte do estado do Rio de Janeiro. Pesquisa Veterinária Brasileira 30:484-490.

Loch, C.; Grando, L. J.; Kieser, J. A. \& Simões-Lopes, P. C. 2011 Dental pathology in dolphins (Cetacea: Delphinidae) from the southern coast of Brazil. Diseases Aquatic Organisms 94:225234.

Marigo, J; Pinto, N. S.; Simões-Lopes, P. C.; Flach, L.; Azevedo, A. F. \& LAILSON-BRITO JR, J. 2013. Case report of flipper anatomic anomaly of Sotalia guianensis from Sepetiba bay, Rio de Janeiro. The Anatomical Record 296:1016-1018.

Montes, I. D.; Chavera, C. A.; van Bresem, M.; Perales, C. R.; Falcón, N. P. \& Van Waerebeek, K. 2004. Descriptión y Evaluación Anatómica de Lesiones óseas Cráneo-mandibulares en Cetáceos Odontocetos del Mar Peruano. Revista de Investigaciones Veterinarias del Perú 15:13-24.

Ogden, J. A.; Conlogue, J. G.; Light, T. R. \& Sloan, T. R. 1981. Fractures of the radius and ulna in a skeletally immature fin whale. Journal of Wildlife Diseases 17:111-116.

Oremland, M. S.; Allen, M. B.; Clapham, P. J.; Moore, M. J.; PotTer, C. \& Mead, J. G. 2010. Mandibular fractures in shortfinned pilot whales, Globicephala macrorhynchus. Marine Mammal Science 26:1-16.

PERrin, W. F. 1975. Variation of spotted and spinner porpoises (genus Stenella) in the Eastern Pacific and Hawaii. Bulletin of the Scripps Institution of Oceanography 21:1-206.

Purves, P. E. \& van Bree, P. J. H. 1972. Evolution and pathology of deep diving in the bottlenosed dolphin, Tursiops truncatus (Montagu, 1821). Beaufortia 20:15-21.

Simões-Lopes, P. C.; Menezes, M. E. \& Ferigolo, J. 2008. Alterações senil-degenetarivas, patológicas, traumáticas e malformações ósseas. In: Monteiro, E. L. A. \& Monteiro, K. D. K. A. eds. Biologia, Ecologia e Conservação do Boto-Cinza. Campinas, IPeC. p.39-50.

Sweeney, J. C. 1978. Infectious Diseases of Body Systems. In: FowLER, M. E. ed. Zoo and Wild Animal Medicine. Philadelphia, Saunders. p.589-592.

Sweeney, J. C. \& Hidway, S. H. 1975. Common Diseases of Small Cetaceans. Journal of the American Veterinary Medica Association 167:533-540.

Sweeney, M. M.; Price, J. M.; Jones, G. S.; French, T. W.; Early, G. A. \& Moore, M. J. 2005. Spondylitic changes in longfinned pilot whales (Globicephala melas) stranded on Cape Cod, Massachusetts, USA, between 1982 and 2000. Journal of Wildlife Diseases 41:717-727.

van Bressem, M. F.; Van Waerebeek, K.; Reyes, J. C.; Félix, F.; Echegaray, M.; Siciliano, S.; Di Benedito, A. P.; Flach, L.; Viddi, F.; Avila, I. C.; Herrera, J. C.; Tobón, I. C.; BolañosJiménez, J.; Moreno, I. B.; Ott, P. H.; Sanino, G. P.; Castineira, E.; Montes, D.; Crespo, E.; Flores, P. A. C.; HaAse, B.; Souza, S. M. F. M.; Laeta, M. \& Fragoso, A. B. 2007. A preliminary overview of skin and skeletal diseases and traumata in smal cetaceans from South American waters. Latin American Journal of Aquatic Mammals 6:7-42. 